\title{
Sociodemographic profile and distribution of Spotted Fever cases per brazilian region between the years 2008 and 2017
}

\author{
Perfil sociodemográfico e distribuição de casos de Febre Maculosa por região brasileira entre os
}

anos de 2008 e 2017

Perfil sociodemográfico y distribución de los casos de Fiebre Manchada por región brasileña entre

los años 2008 y 2017

\begin{abstract}
This study aims to identify the clinical and sociodemographic characteristics of Spotted Fever in Brazil between 2008 and 2017. A descriptive, retrospective, cross-sectional study with a quantitative approach that used as a source of data the Sistema de Informação de Agravos de Notificação (SINAN) available in the public database of the Departamento de Informática do Sistema Único de Saúde (DATASUS), adopting the following variables within the pre-established period: Region of Notification, Sex, Age Group, Evolution, Infection Zone, Schooling, Environment of Infection, and Confirmation Criteria. Spotted fever was prevalent in the Southeast region of the country, although underreporting is a reality in other regions. The most affected population was male, economically active, living in rural areas, and with incomplete primary education. Thus, epidemiological surveillance is fundamental, especially in endemic and "silent" regions for the notification of the disease.
\end{abstract}

Keywords: Spotted fever; Ticks; Rickettsia.

\section{Resumo}

Este trabalho busca identificar as características clínicas e sociodemográficas da Febre Maculosa no Brasil entre 2008 e 2017. Trata-se de um estudo descritivo, retrospectivo, transversal, com abordagem quantitativa que utilizou como fonte de dados o Sistema de Informação de Agravos de Notificação (SINAN) disponíveis no banco de dados públicos do Departamento de Informática do Sistema Único de Saúde (DATASUS), cujas variáveis foram: Região de Notificação, Sexo, Faixa Etária, Evolução, Zona de Infecção, Escolaridade, Ambiente de Infecção e Critério de Confirmação. Foram notificados 1.468 casos de Febre Maculosa no Brasil. A Febre Maculosa foi prevalente na região Sudeste do país, embora a subnotificação seja uma realidade nas demais regiões. A população mais afetada foi do sexo masculino, com idade economicamente ativa, residente de áreas rurais e com ensino fundamental incompleto. Desse modo, a vigilância epidemiológica é fundamental, principalmente nas regiões endêmicas e "silenciosas" para a notificação da doença.

Palavras-chave: Febre maculosa; Carrapatos; Rickettsia. 


\begin{abstract}
Resumen
Este trabajo busca identificar las características clínicas y sociodemográficas de la Fiebre Manchada en Brasil entre 2008 y 2017. Se trata de un estudio descriptivo, retrospectivo, transversal y con enfoque cuantitativo que utilizó como fuente de datos el Sistema de Informação de Agravos de Notificação (SINAN) disponible en la base de datos pública del Departamento de Informática do Sistema Único de Saúde (DATASUS), cuyas variables fueron: Región de Notificación, Sexo, Grupo de Edad, Evolución, Zona de Infección, Escolaridad, Ambiente de Infección y Criterio de Confirmación. Se notificaron 1.468 casos de fiebre manchada en Brasil. La fiebre manchada era prevalente en la región del sureste del país, aunque en las demás regiones la notificación es insuficiente. La población más afectada era masculina, económicamente activa, que vivía en zonas rurales y con estudios primarios incompletos. Por lo tanto, la vigilancia epidemiológica es esencial, especialmente en las regiones endémicas y "silenciosas" para la notificación de la enfermedad.
\end{abstract}

Palabras clave: Fiebre manchada; Garrapata; Rickettsia.

\title{
1. Introduction
}

The Spotted Fever (SF) is a multisystemic pathology, deemed as severe and with an incubation period of 2 to 14 days, presenting, when in its acute stages, normally nonspecific signals and symptoms, such as high fever, myalgia, general sickness, nausea and vomits, which could easily be mistaken with other pathologies, for instance, common arboviral and parasitic diseases (Tiriba, 1999; Greca, 2008).

The etiological agents for the Spotted Fever are the bacteria belonging to the genus Rickettsia, including in such genus some zoonotic agents, namely Rickettsia rickettsii and Rickettsia parkeri, that are able to cause acute human fever diseases, being this the case of Brazilian Spotted Fever (BSF) and Rocky Mountain Spotted Fever (RMSF). In Brazil, Rickettsia rickettsiis is usually transmitted by ticks of the genus Amblyomma, where the A. cajennense species is the one most frequently identified as the disease vector (Quadros, 2021).

The bacteria are commonly spread through nature, via the ticks that play an important part, not only as vectors, but also as reservoirs that could already transmit the $R$. rickettsii to its progeny in a direct manner. This way, the tick remains infected both throughout its whole life cycle and during many more generations after the primary infection, which then reassures the maintenance of an endemic focus (Araujo, 2015).

Considering the factors involved in the disease transmission dynamics, the human beings end up being accidental hosts and the endemic cycle unfolds from focal infections, remaining localized. In Brazil, besides the most common hosts being ticks, there is also Capybaras being classified as natural amplifying hosts for the Amblyomma sculptum species, this one being the most important vectors of $R$. rickettsii to the humans in the country (Durães, 2021; Quadros, 2021).

The most relevant symptom in this pathology is the exanthem that generally shows up between the $3^{\text {rd }}$ and $5^{\text {th }}$ days after the disease has been established, however, it could be absent in around $10 \%$ of patients, which ends up being an even further limitation to the diagnosis, mainly when this difficulty is added to the lack of proper knowledge or information, pertaining the population and healthcare services, potentially being able to lead to a larger number of deaths if these cases are not treated in an adequate time frame, since the mortality rate is directly related to the early diagnosis, and consequently, the immediate compliance to a suitable treatment (Sexton, 2006; Del Fiol, 2010).

Thus, observing the severity of Spotted Fever, as well as being aware of the territorial conditions in which Brazil is inserted, it is valid and fundamental that Public Health has information about the clinical and sociodemographic characteristics of the Spotted Fever cases, even more so in regions where forest zones are more present. Consequently, this work aims to identify the clinical and sociodemographic characteristics of the Spotted Fever in Brazil, between the years 2008 to 2017. 


\section{Materials and methods}

\section{Study Type}

Descriptive, retrospective, cross-sectional study, with a quantitative approach that used as a source of data the Sistema de Informação de Agravos de Notificação (SINAN - National Disease Notification System) available within the public database from the Departamento de Informática do Sistema Único de Saúde (DATASUS - Informatics Department from the Unified Healthcare System), where the notified cases of Spotted Fever in Brazil between the years 2008 and 2017 were collected, including the following variables during the specified period: Region of Notification, Sex, Age Group, Evolution, Infection Zone, Schooling, Infection Environment and Confirmation Criteria. It is important to highlight that all notified data was selected, including those registered as "Ignored/Blank" at the notification file.

The collected data was then organized into spreadsheets using the Microsoft Excel ${ }^{\circledR} 2016$ software, to generate afterwards the graphs presented through this manuscript.

\section{Results}

Between the years of 2008 and 2017 Brazil registered 1.468 cases of Spotted Fever, with an annual mean of 146,8 cases. Moreover, the Southeast Region was the one that presented the bigger number of notified cases, accumulating a total of 1.063 registers, then followed by the South Region with 357 cases, Northeast with 23, Center-West with 20 and the North holds the lowest occurrence, showing only 5 notified cases, as shown on Graph 1.

Graph 1: Distribution of the Spotted Fever cases, according to the Brazilian Regions, between the years 2008-2017.

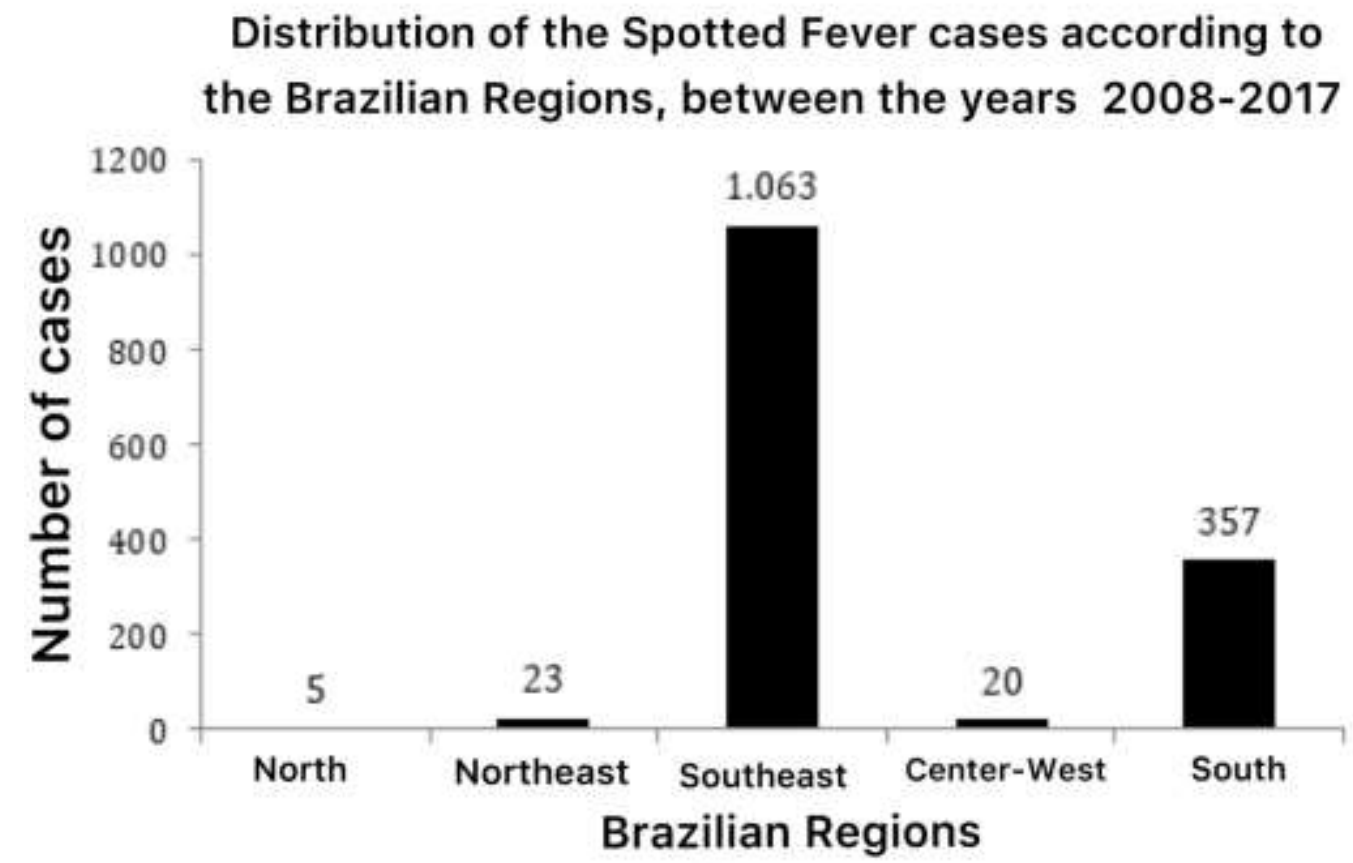

Source: SINAN/DATASUS (2021).

In relation to its sociodemographic profile, most of the cases were men $(71,05 \%)$, simultaneously to the most reported Infection Zone being rural areas $(44,41 \%)$. About the Schooling on the registered cases, $(27,45 \%)$ had incomplete Elementary/Middle School, but most of the cases fell into Ignored/Blank, then summing up a total of 548 (37,33\%) (Table 1). 
In regards to the Infection Environment, it was possible to observe that $507(38,08 \%)$ of the total cases occurred at a residential environment, followed by $368(28,17 \%)$ at a recreational one, $264(20,24 \%)$ at a professional environment, 69 $(5,28 \%)$ cases were classified as other settings and $98(7,5 \%)$ were Ignored/Blank, with a grand total of 1.306 cases, this number being comprehensive of 162 missing reports, when looking at the total of patients diagnosed with SF, this discrepancy than suggests failing in the process of notifying the information.

About the Disease Confirmation Criteria variable, it was possible to state that 1320 (90\%) of the Spotted Fever cases were confirmed by the use of Laboratory Diagnostics, $121(8,24 \%)$ by the use of clinical-epidemiological aspects and 27 $(1,84 \%)$ had no record of the techniques used to confirm the aforementioned pathology, as a result, being classified as Blank/Ignored.

Concerning the age group, all of them had registered cases of Spotted Fever, but the largest number of pathologyaffected individuals was characterized by being 40 to 59 years old (34,60\%), followed by the age range of 20 to 39 years old $(31,47 \%)$ as detailed on Table 1.

Table 1: Sociodemographic Profile of the Spotted Fever cases registered in Brazil during the period from 2008 to 2017.

\begin{tabular}{|c|c|c|}
\hline \multirow[b]{2}{*}{ Variables } & \multicolumn{2}{|c|}{ Total } \\
\hline & N. & $(\%)$ \\
\hline \multicolumn{3}{|l|}{ Sex } \\
\hline Male & 1.043 & 71,05 \\
\hline Female & 425 & 28,95 \\
\hline \multicolumn{3}{|l|}{ Age (in years) } \\
\hline$\leq 5$ & 73 & 4,97 \\
\hline 6 to 9 & 78 & 5,31 \\
\hline 10 to 19 & 165 & 11,24 \\
\hline 20 to 39 & 462 & 31,47 \\
\hline 40 to 59 & 508 & 34,60 \\
\hline $60+$ & 182 & 12,40 \\
\hline \multicolumn{3}{|l|}{ Infection Zone } \\
\hline Urban & 475 & 32,36 \\
\hline Rural & 652 & 44,41 \\
\hline Peri-urban & 198 & 13,49 \\
\hline Ignored/Blank & 143 & 9,74 \\
\hline \multicolumn{3}{|l|}{ Infection Environment } \\
\hline Ignored/Blank & 98 & 7,5 \\
\hline Residential & 507 & 38,08 \\
\hline Professional & 264 & 20,24 \\
\hline Recreational & 368 & 28,17 \\
\hline Others & 69 & 5,28 \\
\hline \multicolumn{3}{|l|}{ Confirmation Criteria } \\
\hline Ignored/Blank & 27 & 1,84 \\
\hline Laboratory & 1320 & 90 \\
\hline Clinical-epidemiological & 121 & 8,24 \\
\hline \multicolumn{3}{|l|}{ Schooling } \\
\hline Illiterate & 13 & 0,89 \\
\hline Incomplete Elementary/Middle School & 403 & 27,45 \\
\hline Complete Elementary/Middle School & 85 & 5,79 \\
\hline Incomplete High School & 64 & 4,36 \\
\hline Complete High School & 162 & 11,04 \\
\hline Incomplete Higher Education & 25 & 1,70 \\
\hline Complete Higher Education & 56 & 3,81 \\
\hline Non applicable (still not in school age) & 112 & 7,63 \\
\hline Ignored/Blank & 548 & 37,33 \\
\hline Total & 1.468 & $\mathbf{1 0 0 , 0 0}$ \\
\hline
\end{tabular}


Amongst those infected with SF, 876 (59,67\%) evolved to a cure, meanwhile 514 (35,01\%) ended up dying due to the notified condition, $13(0,89 \%)$ showed another health complications that ultimately were fatal and $65(4,43 \%)$ had no information on their health status whatsoever.

\section{Discussion}

The fact that the most reported Infection Environment was the residential, even when the Rural Infection Zone is the most predominant amongst the notified cases, could be related to what was called attention to by Nogueira et al. (2005) mentioning that the domestic animals, normally dogs, although being just once infected and presenting low bacterial load, could directly contribute to the spreading of the disease, due to transporting infected ticks to the insides of a residence and then allowing contact to the human beings. This scenario could be confirmed taking into consideration the comments made by Del Fiol et al. (2010) about the characteristics of the disease vector, especially that the ticks of the Amblyomma genus usually live on zones of grassland, lawns or near the rivers.

As in this present study, the authors Szabó, Pinter \& Labruna (2013) and Barros et al. (2014) also debate that the regions with the most expressive number of confirmed cases, were the South and Southeast, where it was possible to observe high lethality levels and that the most disease-affected population was the economically active one. This situation was also approached by Satjanadumorong et al. (2019) upon discussing that the expansion, deforestation and ease with which humans can get access to isolated or hardly populated areas, is what ends up exposing the individuals to uncommon pathogens and vectors, that normally would not be near humans.

According to Oliveira et al. (2016), the North, Northeast and Center-West Regions are considered as silent areas to this disease, because there is a low register of case notifications, both clinically and epidemiologically, even when they present geographic characteristics that favor the presence of some vector species for this condition, this was then corroborated by the findings of prevalence which shows low numbers of confirmed cases throughout these regions, what could suggest a sub notification question, taking into account the general overview of the pathogen and the biology of its vectors.

The lack of complete comprehension about the epidemiological scenario of the Spotted Fever in Brazil, is also a decisive and persistent factor, mainly on the occurrences where there are no full records of exposure, as presented on a case by Oliveira et al. (2018) that described a death happening at the Northeast, in which the patient had no background of trips to well-known endemic areas for this pathology or areas that simply reported cases of the disease.

The first reported cases of Spotted Fever (SF) happened during the 40s, and for a long period of time, it was considered as a rural zone disease, as said by Montenegro et al. (2017), however, the number of cases on the urban and periurban regions are also high. Nevertheless, the urbanization process of this pathology doesn't seem to be common all over Brazil, which could result in the concentration of cases still being maintained at the Rural settings.

The Environment change, inside the current context, could happen as a consequence of environmental disturbance caused by the human beings that generate an unbalance at the natural cycle of the pathology within the wild territory, as also cited by Araújo et al. (2015) that makes a point by saying that SF in Brazil is associated with Rural Transmissions, but it has also been reported in peri-urban and urban zones, despite the fact that the natural habitat of the usual vectors and hosts are not located in such places.

According to the Epidemiological Bulletin from the Health Surveillance Secretary (2019), the male population with economically active age is the most affected by the disease, with proven and observed statistical relevance. Generally, the exposure to ticks by the contact with domestic or wild animals and the visit to forest settings are also considered as risk factors to this group. 
At the epidemiological study done by Freitas et al. (2020) it was demonstrated that most of Rickettsia infections happen on a residential environment, followed by recreational and professional ones, as also described in this study, This data is also described by Nasser et al. (2015), that associates the increasing of houses and buildings in nature zones, the proximity to recreational parks, the larger capybara population and the absence of natural predators, all to a significantly extended exposure of humans to disease vectors and hosts.

Some works, as the ones conducted by Araújo et al. (2015) and Straily et al. (2016) show that kids, younger than 10 years old, were likely to be more frequently exposed to the infection and establishment of SF, due to being in more frequent contact with the dogs that usually are domestic animals, but, the obtained results during the data collection showed that the most affected age range was between 20 to 59 years old, agreeing to the fact that this is the most active age gap on social and economic spheres.

Due to the low specificity of SF symptoms, Del Fiol et al. (2010) and Costa et al. (2016) declare that the early diagnosis is fundamental to minimize patient's ill-effects, being the laboratorial analysis essential to the confirmation of the disease, whether it is by non-specific tests (blood samples and enzymes) or more accurate immune tests, such as Indirect Immunofluorescence, Direct Search for the Rickettsia using methods of Histopathology/Immunohistochemistry and the Polymerase Chain Reaction (PCR).

Rodrigues (2018) brings attention to the fact that low schooling levels contribute to the incidence of infectious diseases, even when the schooling registered was Incomplete Elementary/Middle School, the lack of information about SF can be the main faulty point when talking about prevention. Fact that was also highlighted by Buczek et al. (2020) that emphasizes that knowledge sharing about the transmission pathways, symptoms and prevention of SF need to be more popularized, not only amongst healthcare professionals, but also amongst the population, because it is of utmost importance to the correct treatment and disease epidemiological overview.

\section{Conclusion}

In recent years, it was possible to observe prevalent cases of Spotted Fever in the Southeast Region of the country, although the possibility of disease sub-notification exists throughout the North, Northeast and Center-West Regions. In addition, the disease has shown itself as more prevalent on the male population, with economically active age range (40 to 59 years old), with Incomplete Elementary/Middle Schooling, resident of rural zones and having predominantly home-based infection environment, due to the increasing advance of residential and recreational areas, to the nature and forest regions. Even though it is associated with rural regions, it has also been greatly identified and prevalent in Urban Zones. The diagnose difficulty, mostly because of the non-specific symptoms, makes the diagnostic confirmation criteria become preferably a laboratory test. When discussing disease evolution, around $60 \%$ of cases evolved to a cure, however, the mortality rate of the disease is also worrisome, with over $35 \%$ of cases being fatal.

Therefore, it is necessary to improve the epidemiological surveillance, specially at endemic yet "silent" regions for this disease notification. It is also extremely important that healthcare professionals and public healthcare institutes located in these areas might be ready to diagnose, treat and manage the disease in an adequate manner, by the training that can be offered by the municipal departments of health from the endemic regions and the Ministry of Health. That's why more studies related to the prevalence, signs and simptons and the prevetion of Spotted Fever are essential to reduce the incidence of this disease in our country. 
Research, Society and Development, v. 11, n. 1, e27011124843, 2022

(CC BY 4.0) | ISSN 2525-3409 | DOI: http://dx.doi.org/10.33448/rsd-v11i1.24843

\section{References}

Araújo, R.P.; Navarro, M. B. M. A.; Cardoso, T. A. O. (2015). Febre Maculosa no Brasil: estudo da mortalidade para a vigilância epidemiológica. Cad. Saúde Colet. v. 23, n. 4 , p. 354-61.

Barros-Silva, P. M. R., Pereira, S. V. C., Fonsec, L. X. et al (2014). Febre maculosa: uma análise epidemiológica dos registros do sistema de vigilância do Brasil. Scientia Plena. 10(4).

Brasil. (2019). Ministério da Saúde. Secretaria de Vigilância em Saúde. Boletim epidemiológico, número especial. Febre Maculosa, p. $29-30,2019$.

Buczek, W., Koman-Izko, A., Buczek, A. M. et al. (2020). Spotted fever group rickettsiae transmitted by Dermacentor ticks and determinants of their spread in Europe. Ann Agric Environ Med. 27(4), 505-11.

Costa, G. A.; Carvalho, A. L.; Teixeira, D. C. (2016). Febre maculosa: atualização. Revista Médica de Minas Gerais, v. 26(6), p. 61-4.

Del Fiol, F. S.; Junqueira, F. M.; Rocha; M. C. P. et al. (2010). A Febre Maculosa no Brasil. Rev Panam Salud Publica. 27(6):461-6.

Durães, L. S.; Bitencourth, K.; Ramalho, F. R. et al. (2021). Biodiversity of Potential Vectors of Rickettsiae and Epidemiological Mosaic of Spotted Fever in the State of Paraná, Brazil. Frontiers in Public Health, v. 9, p. 161.

Freitas, R. S.; Silva, G. R. S.; Alexandre, T. F. et al. (2020). Urbanização da Febre Maculosa nas Regiões Sul e Sudeste do Brasil. In: Batista JS, Teófilo TS. Medicina Veterinária: Casos Clínicos Envoltos. Ponta Grossa, PR: Atena. p. 58-67.

Greca, H.; Langoni, H.; Souza, L. C. (2008). Brazilian spotted fever: a reemergent zoonosis. J Venom Anim Toxins Incl Trop Dis. 14(1):3-18.

Montenegro, D. C.; Bitencourth, K.; Oliveira, S. V. et al. (2017). Spotted fever: epidemiology and vector-rickettsia-host relationship in Rio de Janeiro state. Frontiers in microbiology, v. 8, p. 505.

Nasser, J. T.; Lana, R. C.; Silva, C. M. S. et al. (2015). Urbanização da febre maculosa brasileira em município da região Sudeste: epidemiologia e distribuição espacial. Rev Bras Epidemiol, 18 (2), p. 299-312.

Nogueira, A. H. C.; Barci, L. A. G.; Ferrari, C. I. L. (2005). Febre maculosa. Pesquisa \& Tecnologia. v. 2 , n. 2.

Oliveira, S. V.; Angerami, R. N. (2018). Timeliness in the notification of spotted fever in Brazil: Evaluating compulsory reporting strategies and digital disease detection. International Journal of Infectious Diseases, v. 72, p. 16-18.

Oliveira, S. V.; Pereira, S. V. C.; Pinna, F. V. et al. (2016). Vigilância de ambientes da febre maculosa: explorando as áreas silenciosas do Brasil. Rev PanAmaz Saude, Ananindeua, v. 7, n. 3, p. 65-72.

Quadros, A. P. N.; Rego, G. M. S.; Silva, T. F. et al. (2021). Capybara (Hydrochoerus hydrochaeris) exposure to Rickettsia in the Federal District of Brazil, a non-endemic area for Brazilian spotted fever. Revista Brasileira de Parasitologia Veterinária, v. 30.

Rodrigues, V. F. (2018) Ectoparasitoses: acometimento humano, agravos clínicos e casos negligenciados no Brasil [Monografia]. Brasília (DF): Faculdade de Ciências da Educação e Saúde, Centro Universitário de Brasília, Brasília. 23 p.

Satjanadumrong, J.; Robinson, T. R.; Hughes, T. et al. (2019). Distribution and ecological drivers of spotted fever group Rickettsia in Asia. EcoHealth;16(4):611-626.

Sexton, D. J. \& Walker, D. H. (2006). Spotted fever group rickettsioses. In: Guerrant RL, Walker DH, Weller PF (eds.). Tropical infectious diseases: principles, pathogens, and practice. Philadelphia: Churchill Livingstone; p. 539-47.

Straily, A.; Drexler, N.; Cruz-Loustaunau, D. et al. (2016). Notes from the Field: Community-Based Prevention of Rocky Mountain Spotted Fever — Sonora, Mexico. MMWR Morb Mortal Wkly; 65: 1302-03.

Szabó, M. P. J.; Pinter, A.; Labruna, M. B. (2013). Ecology, biology and distribuition of spotted-fever tick vectors in Brazil. Front Cell Infect Microbiol. 3:27. PMid:23875178.

Tiriba, A. C. (1999). Doenças causadas por rickettsias. In: Veronesi R, Focaccia R, organizadores. Tratado de Infectologia. São Paulo: Atheneu. p. 528-9. 